Prepared in cooperation with the Triangle Area Water Supply Monitoring Project Steering Committee

\title{
Quality of Surface-Water Supplies in the Triangle Area of North Carolina, Water Year 2008
}
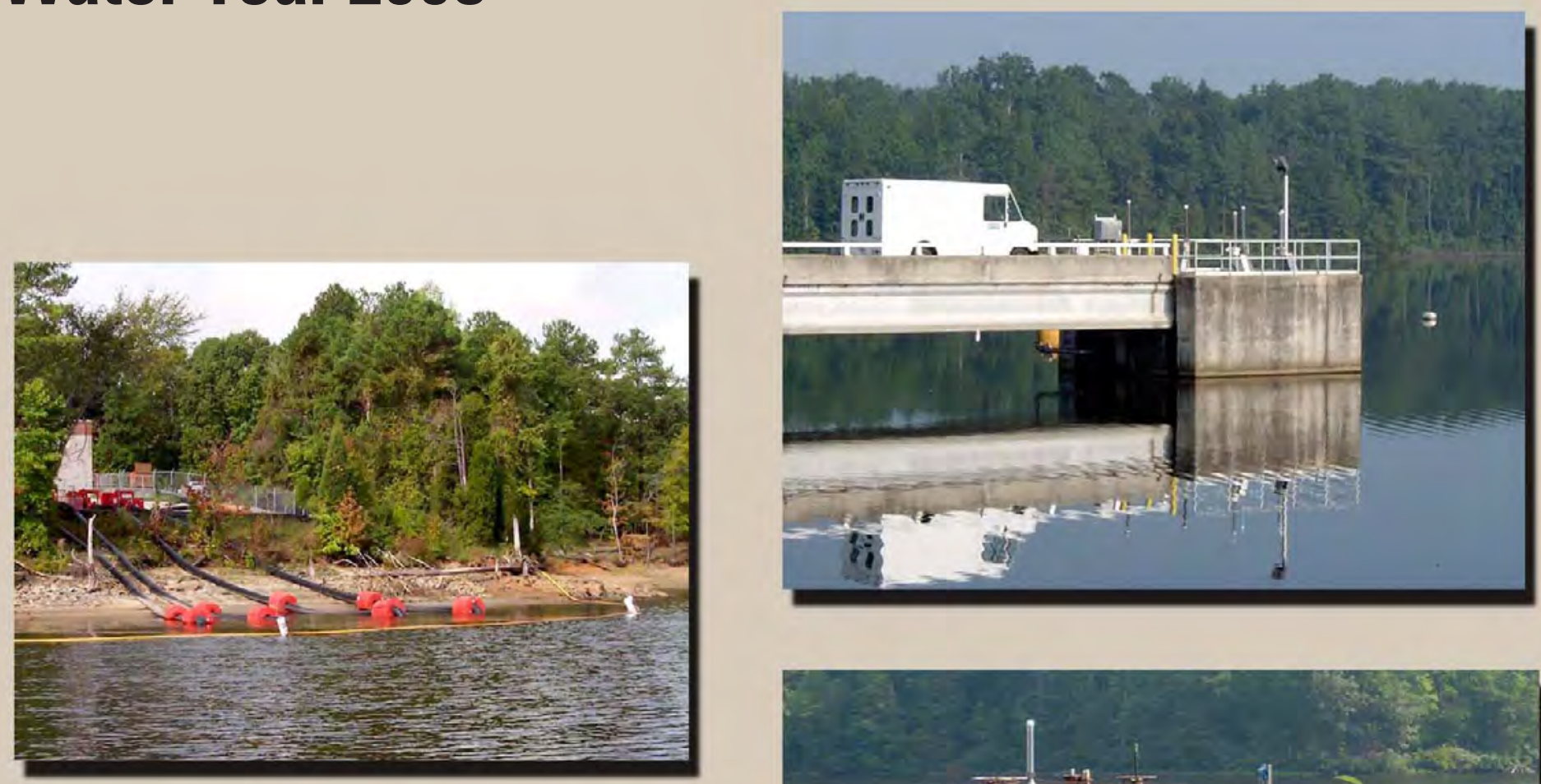

Open-File Report 2012-1013

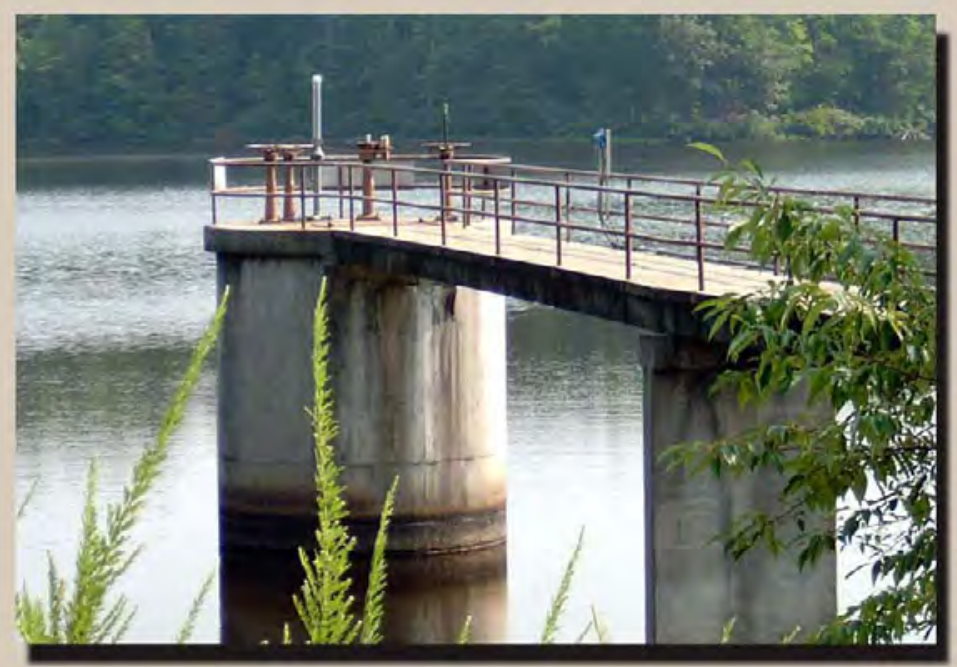

U.S. Department of the Interior U.S. Geological Survey 


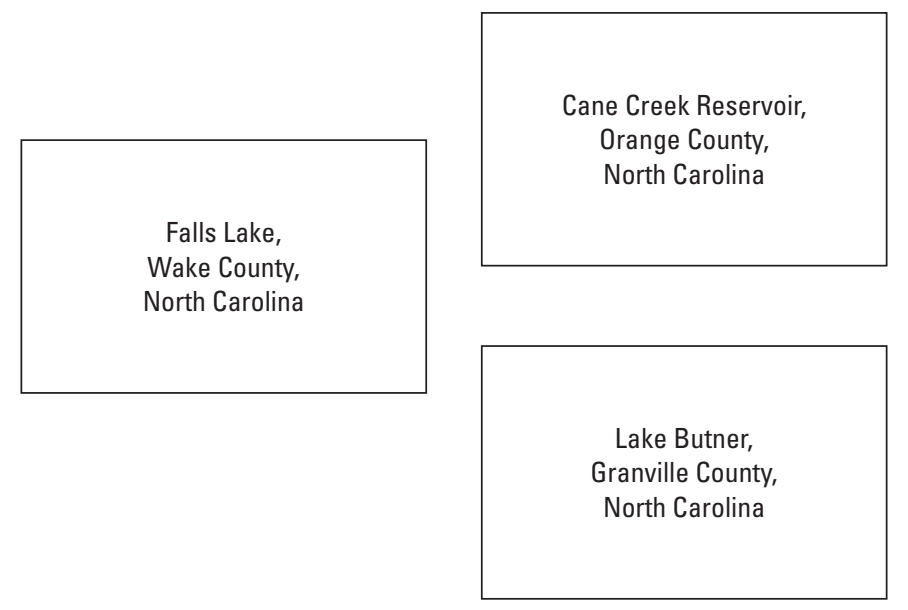




\section{Quality of Surface-Water Supplies in the Triangle Area of North Carolina, Water Year 2008}

By M.J. Giorgino, R.B. Rasmussen, and C.A. Pfeifle

Prepared in cooperation with the Triangle Area Water Supply Monitoring Project

Steering Committee

Open-File Report 2012-1013 


\title{
U.S. Department of the Interior \\ KEN SALAZAR, Secretary \\ U.S. Geological Survey \\ Marcia K. McNutt, Director
}

\author{
U.S. Geological Survey, Reston, Virginia: 2012
}

For more information on the USGS - the Federal source for science about the Earth, its natural and living resources, natural hazards, and the environment, visit http://Www.usgs.gov or call 1-888-ASK-USGS.

For an overview of USGS information products, including maps, imagery, and publications, visit $h t t p: / / w w w . u s g s . g o v / p u b p r o d$

To order this and other USGS information products, visit http://store.usgs.gov

Any use of trade, product, or firm names is for descriptive purposes only and does not imply endorsement by the U.S. Government.

Although this report is in the public domain, permission must be secured from the individual copyright owners to reproduce any copyrighted materials contained within this report.

Suggested citation:

Giorgino, M.J., Rasmussen, R.A., and Pfeifle, C.A., 2012, Quality of surface-water supplies in the Triangle area of North Carolina, water year 2008: U.S. Geological Survey Open-File Report 2012-1013, 12 p. 


\section{Contents}

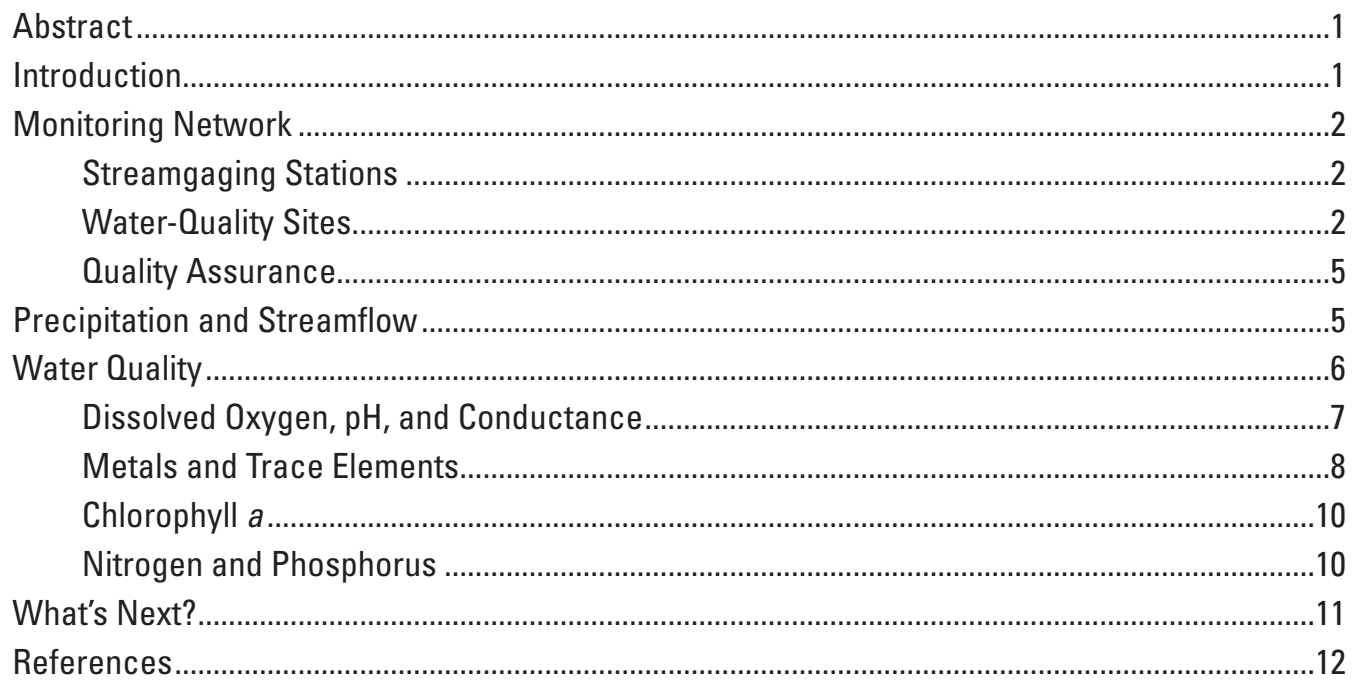

\section{Figures}

1. Map showing location of Triangle Area Water Supply Monitoring Project data-collection sites in the upper Cape Fear and Neuse River Basins, North Carolina ...

2-5. Graphs showing:

2. Monthly precipitation at the Raleigh-Durham International Airport, North Carolina (NOAA National Weather Service station KRDU), October 2007 through September 2008

3. Palmer Hydrological Drought Index values for the Northern Piedmont and Central Piedmont climate divisions of North Carolina, October 2007 through September 2008

4. Annual runoff measured from October 2007 through September 2008 and normal runoff for the period of record at 10 U.S. Geological Survey streamgaging stations in the Triangle area of North Carolina.

5. Seven-day average streamflow, at U.S. Geological Survey site 1, Eno River at Hillsborough in the Neuse River Basin; and U.S. Geological Survey site 19, Haw River near Bynum in the Cape Fear River Basin, for the period October 2007 through September 2008

6-8. Maps showing:

6. Sites in the Triangle area of North Carolina with one or more measurement of dissolved-oxygen concentration less than 5 milligrams per liter and dissolved-oxygen percent saturation value greater than 110 percent, 0 ctober 2007 through September 2008.

7. Sites in the Triangle area of North Carolina with one or more concentration of unfiltered iron greater than 1,000 micrograms per liter, unfiltered manganese greater than 200 micrograms per liter, unfiltered mercury greater than 0.012 microgram per liter, and unfiltered copper greater than 7 micrograms per liter, October 2007 through September 2008. 
8. Sites in the Triangle area of North Carolina with one or more chlorophyll a concentration greater than 40 micrograms per liter, October 2007 through September 2008.

9. Graphs showing dot plots of concentrations of total ammonia plus organic nitrogen and total phosphorus at sites in the Triangle Area Water Supply Monitoring Project study area, October 2007 through September 2008

\section{Tables}

1. Water-quality and streamflow monitoring sites for the Triangle Area Water Supply Monitoring Project, October 2007 through September 2008

2. Summary of water-quality results for sampling sites in the Triangle Area Water Supply Monitoring Project, October 2007 through September 2008 Separate Excel file

\section{Conversion Factors}

Inch/Pound to SI

\begin{tabular}{|c|c|c|}
\hline Multiply & By & To obtain \\
\hline \multicolumn{3}{|c|}{ Length } \\
\hline inch (in.) & 2.54 & millimeter (mm) \\
\hline mile (mi) & 1.609 & kilometer $(\mathrm{km})$ \\
\hline \multicolumn{3}{|c|}{ Flow rate } \\
\hline cubic foot per second $\left(\mathrm{ft}^{3} / \mathrm{s}\right)$ & 0.02832 & cubic meter per second $\left(\mathrm{m}^{3} / \mathrm{s}\right)$ \\
\hline
\end{tabular}

Specific conductance is given in microsiemens per centimeter at 25 degrees Celsius $\left(\mu \mathrm{S} / \mathrm{cm}\right.$ at $\left.25^{\circ} \mathrm{C}\right)$.

Concentrations of chemical constituents in water are given either in milligrams per liter (mg/L) or micrograms per liter $(\mu \mathrm{g} / \mathrm{L})$.

\section{Selected acronyms and abbreviations used in this report:}

$\begin{array}{ll}\text { DOC } & \text { dissolved organic carbon } \\ \text { MCL } & \text { maximum contaminant level } \\ \text { NCDWO } & \text { North Carolina Division of Water Quality } \\ \text { SDWR } & \text { secondary drinking-water regulation } \\ \text { TAWSMP } & \text { Triangle Area Water Supply Monitoring Project } \\ \text { USGS } & \text { U.S. Geological Survey }\end{array}$




\title{
Quality of Surface-Water Supplies in the Triangle Area of North Carolina, Water Year 2008
}

\author{
By Mary J. Giorgino, R.B. Rasmussen, and C.A. Pfeifle
}

\begin{abstract}
Surface-water supplies are important sources of drinking water for residents in the Triangle area of North Carolina, which is located within the upper Cape Fear and Neuse River Basins. Since 1988, the U.S. Geological Survey and a consortium of governments have tracked water-quality conditions and trends in several of the area's water-supply lakes and streams. This report summarizes data collected through this cooperative effort, known as the Triangle Area Water Supply Monitoring Project, during October 2007 through September 2008. Major findings for this period include:
\end{abstract}

- Antecedent drought conditions during 2007 contributed to below-average flows at streams throughout the study area during 2008. Continuous records from 9 of the 10 project stream gages documented below-average streamflow during most of the year.

- More than 8,000 individual measurements of water quality were made at a total of 27 sites - 15 in the Neuse River Basin and 12 in the Cape Fear River Basin.

- North Carolina water-quality standards were exceeded one or more times for nine constituents, including dissolved oxygen, dissolved oxygen percent saturation, $\mathrm{pH}$, chlorophyll $a$, mercury, copper, iron, manganese, and zinc. Exceedances occurred at 26 sites, 14 of which were in the Neuse River Basin, and 12 of which were in the Cape Fear River Basin.

- Stream samples collected during storm events contained elevated concentrations of iron, copper, and total phosphorus relative to non-storm samples.

- The first full year of sampling was completed for a new project site at Lake Butner in Granville County. Among all lakes sampled during 2008, Lake Butner had the lowest concentrations of total ammonia plus organic nitrogen, total phosphorus, chlorophyll a, and specific conductance and the highest water clarity.
- Concentrations of nitrogen and phosphorus were within ranges observed during previous years; however, Falls Lake at U.S. Interstate 85 had elevated levels of nitrate plus nitrite and total phosphorus relative to other sites.

- Five lakes had chlorophyll $a$ concentrations in excess of 40 micrograms per liter at least once during 2008, including Little River Reservoir, Falls Lake, Lake Benson, University Lake, and Jordan Lake.

\section{Introduction}

The Triangle area of North Carolina, located within the upper Cape Fear and Neuse River Basins, is one of the most rapidly developing areas of the State. Population growth continues to increase demands for water from public suppliers, the majority of which draw water from streams and lakes in the region. Growth also brings the threat of greater loads of pollutants and new contaminant sources that, if not properly managed, could adversely affect water quality.

For the past 20 years, the Triangle Area Water Supply Monitoring Project (TAWSMP) has tracked water-quality conditions and long-term trends in many of the area's water-supply lakes, rivers, and tributaries. The project has progressed in phases, allowing for flexibility in the monitoring network and partners and for focusing on specific water-quality issues as they arose (http://nc.water.usgs.gov/projects/triangle/overview.html). The project currently is in its sixth phase, which covers the period July 2007 through June 2012. Objectives for this phase are to

- Extend the existing water-quality database for nutrients, sediment, major ions, and metals and trace elements to track spatial variations in water quality, loads to lakes, and long-term water-quality trends.

- Continue monitoring at tributary sites during high-flow events to increase the understanding of constituent concentrations and loads during extreme hydrologic conditions. 
- Investigate the occurrence of mercury in water and sediment.

- Maintain a network of 10 continuous streamgaging stations in the study area.

- Publish an analysis of water-quality trends.

Pursuant to an agreement with several local governments, the U.S. Geological Survey (USGS) collects water samples up to six times a year at 30 sites, depending on the location and constituents being monitored. One additional site consists only of a streamflow gage. Water temperature, dissolved oxygen, $\mathrm{pH}$, and specific conductance are measured, and analyses are performed to determine concentrations of nutrients, metals and trace elements, major ions, and total organic carbon at all sites. In addition, suspended-sediment concentrations are measured at stream sites, and chlorophyll $a$ is analyzed at lake sites. Continuous streamflow is recorded at almost all of the stream sites and is funded through the TAWSMP and other USGS cooperative programs. The USGS also is responsible for data quality assurance, analysis, and interpretation, providing the data to the public and maintaining the data in perpetuity. Funding for the project is provided by local government partners (see sidebar) and by the USGS Cooperative Water Program (http://water.usgs.gov/coop/). The Triangle J Council of Governments provides organizational support services for the TAWSMP.

Triangle Area Water Supply
Monitoring Project Partners, 2008
Chatham County
Orange County
Wake County
Town of Apex
Town of Cary
City of Durham
Town of Hillsborough
Town of Morrisville
City of Raleigh
Orange Water and Sewer Authority
South Granville Water and Sewer Authority
Triangle J Council of Governments
U.S. Geological Survey
For more information on the project, go to:
http://nc.water.usgs.gov/projects/triangle/

This report summarizes monitoring activities and data collected by the USGS for the TAWSMP during October 2007 through September 2008, also referred to as water year 2008. Hydrologic conditions in the Triangle area also are described. Ranges of concentrations for water-quality field properties, major ions, nutrients, metals and trace elements, chlorophyll $a$, organic carbon, and suspended sediment are presented for each site sampled during this period.

\section{Monitoring Network}

Since the project began in 1988, several adjustments have been made to sampling locations, sampling frequency, and constituents that are sampled. During 2008, the TAWSMP monitoring network was composed of 31 sites, including streamgaging stations and stream and lake water-quality sites. Project sampling and analytical methods and quality-assurance practices are described by Oblinger (2004).

\section{Streamgaging Stations}

Streamflow records are useful for managing water supplies and are essential for determining in-stream loads of sediment, nutrients, and other constituents and for interpreting water-quality trends. The USGS operates 10 continuous-record streamgaging stations that are funded through the TAWSMP (table 1). These gages record water level and discharge at 15 -minute intervals and display them in near-real time through the National Water Information System Web interface commonly known as NWISWeb (http://waterdata.usgs.gov/nc/nwis/current/?type=flow). Precipitation and streamflow data for several additional sites in the study area are available through other USGS programs.

\section{Water-Quality Sites}

Water-quality data are used to track current conditions and to analyze long-term water-quality trends and pollutant loads in the Triangle area. The USGS monitored water quality at 27 different sites in the TAWSMP study area during water year 2008. More than 8,000 individual water-quality measurements were made, not including vertical-profile measurements in study area lakes. USGS water-quality data are available to project partners and the public through the NWIS-Web (http://nwis.waterdata.usgs.gov/ $n c / n w i s / q w d a t a)$ or by request from the USGS North Carolina Water Science Center (http://nc.water.usgs.gov/index.html).

Nine Triangle area public water-supply lakes are sampled as part of the TAWSMP. Little River Reservoir, Lake Michie, Lake Butner, Falls Lake, Lake Wheeler, and Lake Benson are located in the Neuse River Basin, and Cane Creek Reservoir, University Lake, and Jordan Lake are located in the Cape Fear River Basin (fig. 1). Falls and Jordan Lakes are large, multipurpose reservoirs managed by the U.S. Army Corps of Engineers. The seven smaller lakes are used primarily for water supply; however, most of the lakes also provide recreational access for area residents.

The USGS routinely samples four sites at Falls Lake and four sites at Jordan Lake six times per year. One site in each of the seven smaller lakes is sampled four times per year. At the 15 lake sites, vertical profiles of field properties (water temperature, dissolved oxygen, specific conductance, and $\mathrm{pH}$ ) are measured, along with secchi disk transparency. Water samples are collected for analysis of alkalinity, nutrients, major ions, iron, manganese, total organic carbon, and chlorophyll $a$. Additional metals and trace elements are sampled twice each year. 
Table 1. Water-quality and streamflow monitoring sites for the Triangle Area Water Supply Monitoring Project, October 2007 through September 2008.

[USGS, U.S. Geological Survey; runoff, sampled only during runoff events; n/a, not applicable for lake sites; --, data were not collected (refer to footnote); USACE, U.S. Army Corps of Engineers; italics indicate site is located in waters listed as impaired by the North Carolina Department of Environment and Natural Resources, Division of Water Quality (2007a) at the time of sampling]

\begin{tabular}{|c|c|c|c|c|c|}
\hline \multirow[b]{2}{*}{$\begin{array}{c}\text { Map } \\
\text { no. } \\
\text { (fig. 1) }\end{array}$} & \multirow[b]{2}{*}{$\begin{array}{l}\text { USGS } \\
\text { station no. }\end{array}$} & \multirow[b]{2}{*}{ Station location in North Carolina } & \multirow[b]{2}{*}{ Site type } & \multicolumn{2}{|r|}{ Data collected during $2008 ?$} \\
\hline & & & & $\begin{array}{l}\text { Water } \\
\text { quality }\end{array}$ & $\begin{array}{c}\text { Continuous } \\
\text { streamflow } \\
\text { [period of record] }\end{array}$ \\
\hline \multicolumn{6}{|c|}{ Neuse River Basin } \\
\hline 1 & 02085000 & Eno River at Hillsborough & Stream & Yes & Yes [1927-present] \\
\hline 2 & 02085070 & Eno River near Durham & Stream (runoff) & No & Yes [1963-present] \\
\hline 4 & 0208524845 & Little River Reservoir at dam near Bahama & Lake & Yes & $\mathrm{n} / \mathrm{a}$ \\
\hline 5 & 02085500 & Flat River at Bahama & Stream (runoff) & Yes & Yes [1925-present] \\
\hline 6 & 02086490 & Lake Michie at dam near Bahama & Lake & Yes & $\mathrm{n} / \mathrm{a}$ \\
\hline 7 & 02086569 & Lake Butner at dam near Butner & Lake & Yes & $\mathrm{n} / \mathrm{a}$ \\
\hline 11 & 0208700780 & Little Lick Creek above SR 1814 near Oak Grove & Stream (runoff) & Yes & $-^{2}$ \\
\hline 12 & 0208703650 & Falls Lake at NC Highway 50 near Sandy Plain & Lake & Yes & $\mathrm{n} / \mathrm{a}$ \\
\hline 13 & 0208708905 & Falls Lake at NC Highway 98 near Bayleaf & Lake & Yes & $\mathrm{n} / \mathrm{a}$ \\
\hline 14 & 0208718195 & Falls Lake above dam at Falls & Lake & Yes & $\mathrm{n} / \mathrm{a}$ \\
\hline 15 & 02087588 & Lake Wheeler on Swift Creek near Raleigh & Lake & Yes & $\mathrm{n} / \mathrm{a}$ \\
\hline 16 & 02087701 & Lake Benson at dam near Garner & Lake & Yes & $\mathrm{n} / \mathrm{a}$ \\
\hline \multicolumn{6}{|c|}{ Cape Fear River Basin } \\
\hline 17 & 02096846 & Cane Creek near Orange Grove & Stream & Yes & Yes [1988-present] \\
\hline 18 & 0209684980 & Cane Creek Reservoir at dam near White Cross & Lake & Yes & $\mathrm{n} / \mathrm{a}$ \\
\hline 25 & 02097517 & Morgan Creek near Chapel Hill & $\begin{array}{l}\text { Streamflow } \\
\text { only }\end{array}$ & $\mathrm{n} / \mathrm{a}$ & Yes [1982-present] \\
\hline 26 & 02097521 & Morgan Creek near Farrington & Stream (runoff) & No & $--^{3}$ \\
\hline 27 & 0209768310 & B. Everett Jordan Lake at buoy 12 at Farrington & Lake & Yes & $\mathrm{n} / \mathrm{a}$ \\
\hline 28 & 0209782609 & White Oak Creek at mouth near Green Level & Stream & Yes & Yes [1999-present] \\
\hline 29 & 0209799150 & B. Everett Jordan Lake above U.S. Highway 64 at Wilsonville & Lake & Yes & $\mathrm{n} / \mathrm{a}$ \\
\hline 30 & 0209801100 & $\begin{array}{l}\text { B. Everett Jordan Lake at Bells Landing near Griffins } \\
\text { Crossroads }\end{array}$ & Lake & Yes & $\mathrm{n} / \mathrm{a}$ \\
\hline 31 & 02098198 & Haw River below B. Everett Jordan Lake dam near Moncure & Stream (runoff) & Yes & $-{ }^{4}$ \\
\hline
\end{tabular}

\footnotetext{
${ }^{1}$ Gage funded through separate agreement with agency shown in parentheses.

${ }^{2}$ Instantaneous streamflow measured during sampling.

${ }^{3}$ Streamflow from nearby gage, USGS station 02097517.

${ }^{4}$ Streamflow computed from USACE releases from the Jordan Lake dam.
} 


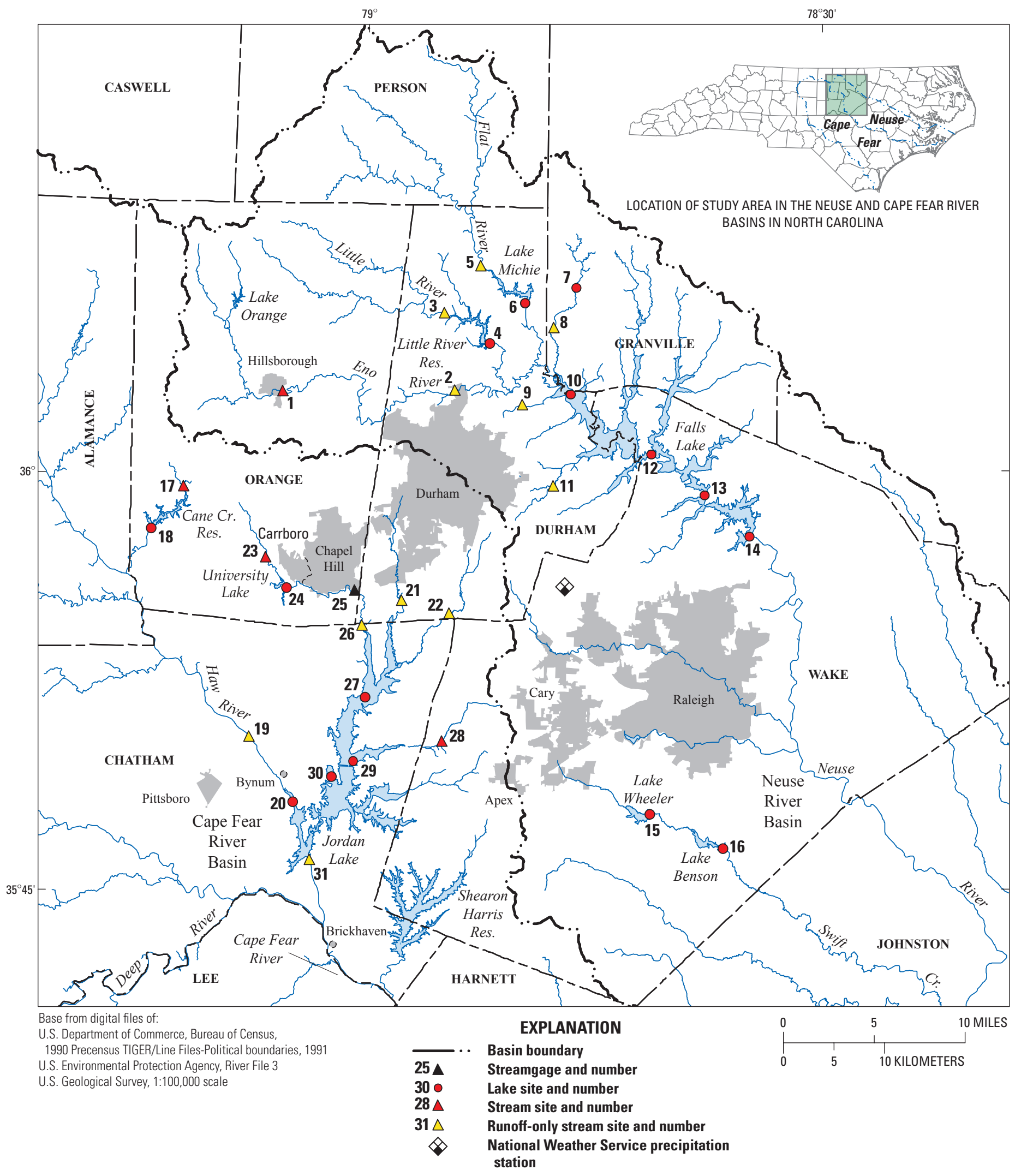

Figure 1. Location of Triangle Area Water Supply Monitoring Project data-collection sites in the upper Cape Fear and Neuse River Basins, North Carolina. 
Four stream sites are routinely sampled by the USGS on a bimonthly basis for field properties, nutrients, major ions, total organic carbon, and suspended sediment, and twice per year for metals and trace elements (table 1). Eleven additional stream sites are sampled by the USGS only during selected storm-runoff events to supplement data that are collected monthly by the North Carolina Division of Water Quality (NCDWQ) Ambient Monitoring Network. These runoff-only stream sites are not all sampled by the USGS during every year. A project goal is to collect 16 runoff-event samples each year; the actual number varies from year to year depending on whether targeted flow conditions occur.

Alkalinity is determined in the field at the time of sampling. Other chemical analyses are performed at the USGS National Water Quality Laboratory in Denver, Colorado. Suspendedsediment samples are analyzed at the USGS Eastern Region Sediment Laboratory in Louisville, Kentucky.

During water year 2008, routine sampling of the 15 lake sites and 4 stream sites was conducted on schedule with the following exceptions. Low water prevented access to Falls Lake at U.S. Interstate 85 during December 2007. Cane Creek and Morgan Creek near White Cross were not sampled during October and December 2007 because both streams were dry. White Oak Creek was stagnant with no observable flow during December 2007; therefore, samples were not collected.

Eight runoff sites were sampled once or twice, resulting in a total of 12 samples (table 1). It is important to note that results for the eight streams sampled only during runoff events likely do not represent typical water-quality conditions for these streams. In addition, one runoff-event sample was collected at Cane Creek (site 17), which is a bimonthly stream site, during September 2008.

\section{Quality Assurance}

Quality-control samples, including deionized water blanks, sampling equipment blanks, field blanks, and replicate environmental samples, were collected and reviewed throughout the year to ensure that project data-quality objectives were met (Oblinger, 2004). Approximately 15 percent of the total number of samples collected were quality-control samples. A review of the quality-control and environmental data revealed that capsule filters had contaminated two samples for dissolved organic carbon (DOC) during April 2008. Consequently, a Teflon filtration apparatus and glass fiber filters were subsequently used for processing DOC samples, and the contaminated results were rejected. No other quality-assurance problems were observed.

\section{Precipitation and Streamflow}

Antecedent drought conditions during water year 2007 contributed to below-average flows at streams throughout the study area during water year 2008. Flows were below average despite the fact that precipitation measured at the National Weather Service station at the Raleigh-Durham International Airport (fig. 1) from
October 2007 through September 2008 totaled 51.6 inches, which exceeded the long-term average annual precipitation of 43.1 inches (fig. 2). The yearly total included more than 9 inches of rain that fell during September 2008; rainfall for prior months in water year 2008 was more typical of long-term average amounts (fig. 2).

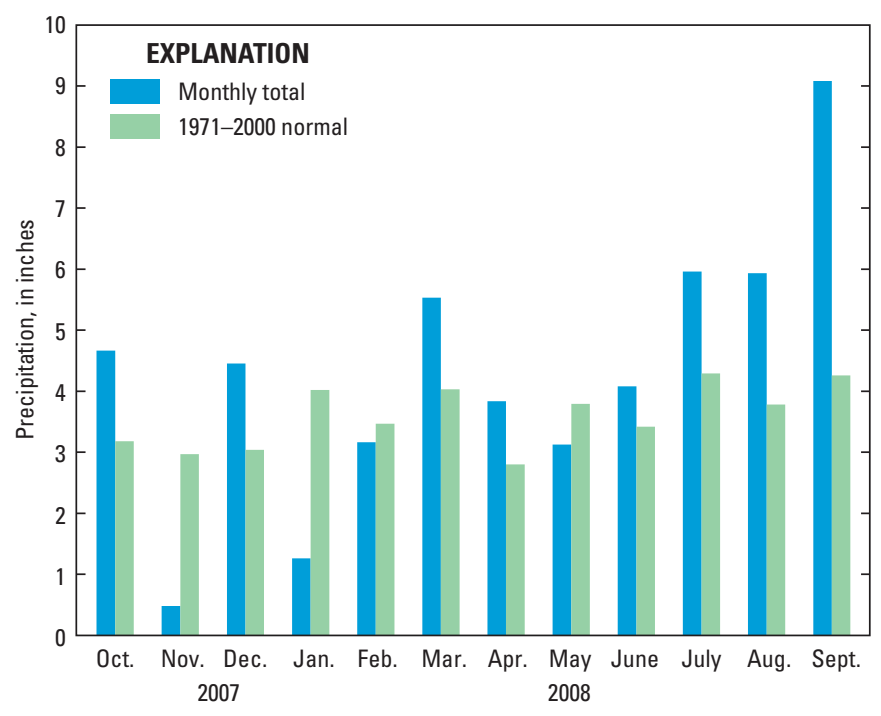

Figure 2. Monthly precipitation at the Raleigh-Durham International Airport, North Carolina (NOAA National Weather Service station KRDU), October 2007 through September 2008 (Location shown in fig. 1. Source: State Climate Office of North Carolina (2008b)).

A better indication of hydrologic conditions is provided by the monthly Palmer Hydrological Drought Index scores for water year 2008 (fig. 3). This index reflects the long-term, cumulative effects of drought on hydrologic characteristics, such as lake levels and streamflow. Negative values indicate dry periods, and positive values indicate wet periods. The Palmer Hydrological Drought Index indicates that dry conditions prevailed during October 2007 through August 2008 in the Northern Piedmont (including Orange, Durham, and Granville Counties) and during October 2007 through September 2008 in the Central Piedmont (including Chatham and Wake Counties) of North Carolina (fig. 3).

Streamflow data collected at the 10 gaging stations funded by the TAWSMP were reviewed, quality-assured, and published in the 2008 USGS Annual Water Data Report (http://nc.water.usgs.gov/reports/WDR/). The data also are available online through the USGS NWIS-Web (http://waterdata. usgs.gov/nc/nwis/). Streamflow during water year 2008 was lower than normal at all sites in the study area, with the exception of Northeast Creek near Genlee (site 22; fig. 4). At this site and New Hope Creek near Blands (site 21), a high percentage of the in-stream flow consisted of treated effluent from municipal water reclamation facilities. These continuous inputs mitigated the effects of drought on streamflow. Drought conditions were especially pronounced at Cane Creek near Orange Grove (site 17) and Morgan Creek near White Cross (site 23), which are headwater streams with small drainage areas, and at the Eno River at Hillsborough (site 1), which is located downstream from a municipal water-supply diversion. 


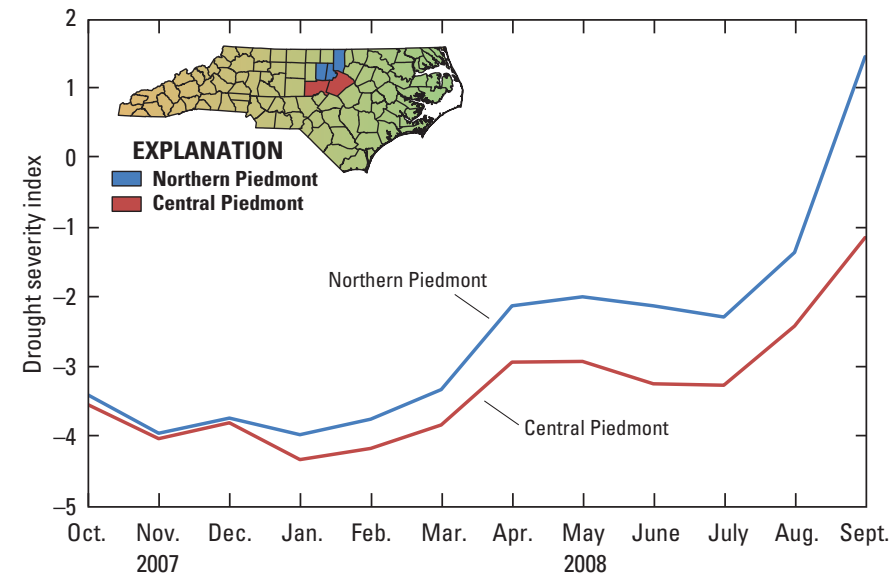

Figure 3. Palmer Hydrological Drought Index for the Northern Piedmont and Central Piedmont climate divisions of North Carolina, October 2007 through September 2008 (Source: State Climate Office of North Carolina (2008a)).

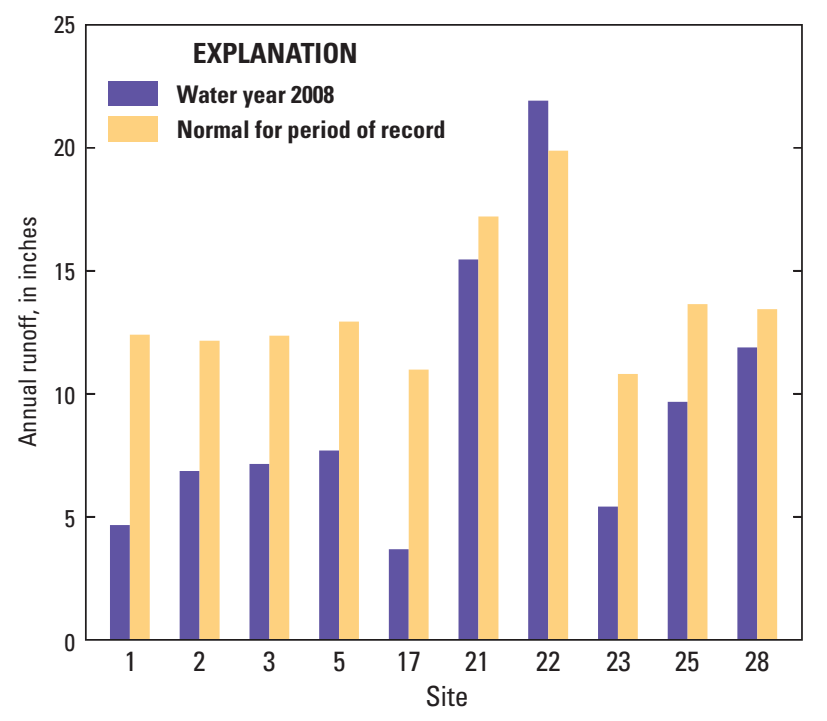

Figure 4. Annual runoff measured from October 2007 through September 2008 and normal runoff for the period of record at 10 U.S. Geological Survey streamgaging stations in the Triangle area of North Carolina.

Below-average flow conditions that were prevalent during the spring and summer of 2007 persisted through much of water year 2008 as illustrated by hydrographs for the Eno River at Hillsborough in the Neuse River Basin and the Haw River near Bynum in the Cape Fear River Basin (fig. 5). Only in late August through September 2008 did flows approximate normal levels, except for brief pulses in response to storm events. Periods of zero flow were recorded at five streams in the study area during October 2007, including Little River near Orange Factory (site 3), Flat River at Bahama (site 5), Cane Creek near Orange Grove (site 17), Morgan Creek near White Cross (site 23), and White Oak Creek near Green Level (site 28).

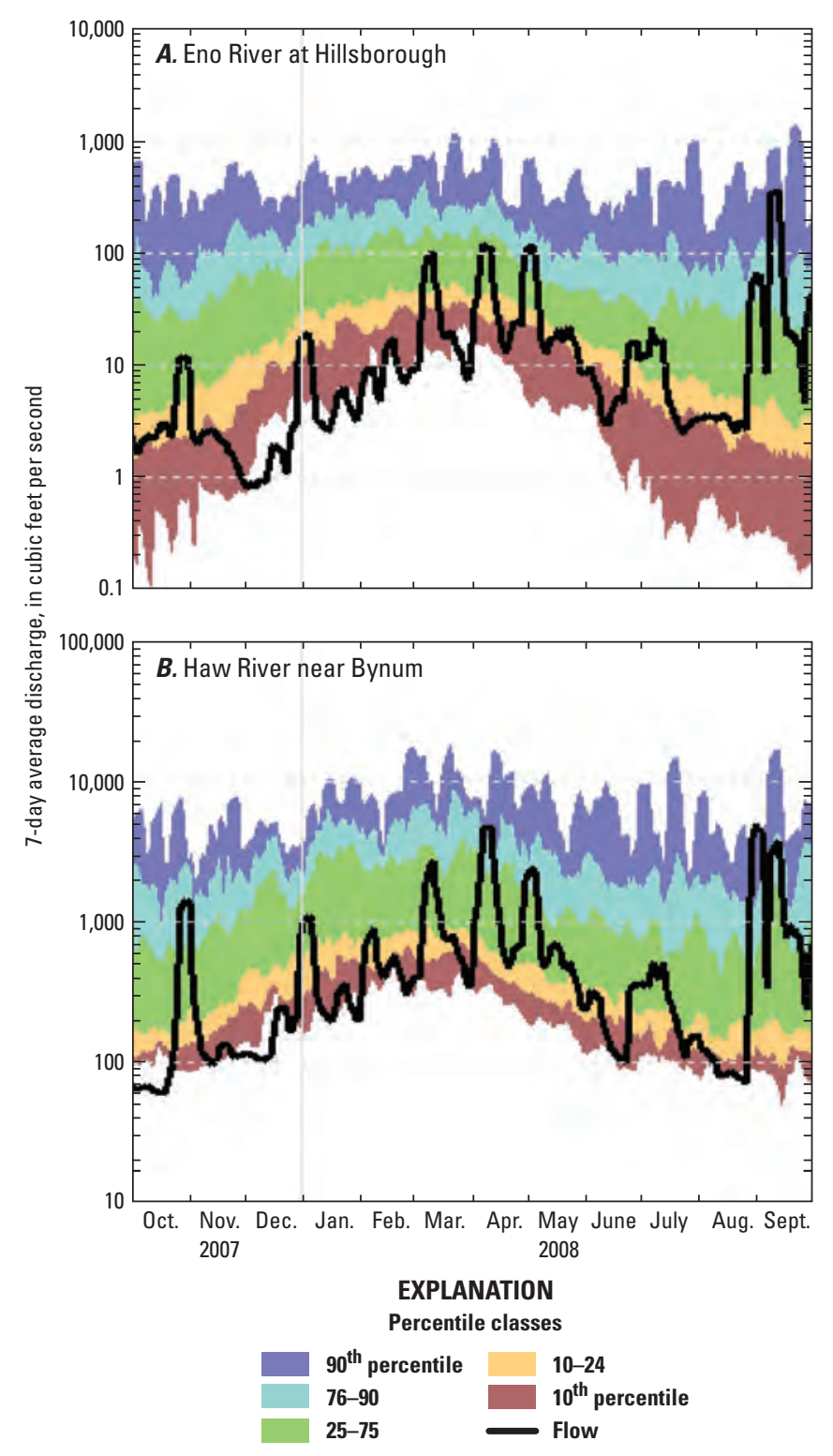

Figure 5. Seven-day average streamflow, in cubic feet per second, at $(A)$ site 1, Eno River at Hillsborough in the Neuse River Basin; and $(B)$ site 19, Haw River near Bynum in the Cape Fear River Basin, for the period October 2007 through September 2008 (locations in fig. 1 and table 1).

\section{Water Quality}

Water-quality data were reviewed, quality-assured, and published in the USGS 2008 Annual Water Data Report (http://nc.water.usgs.gov/reports/WDR/). The data also are available online through the NWIS-Web (http://waterdata.usgs.gov/nc/nwis/). Ranges of concentrations observed at each site for 46 properties or constituents are presented in table 2 (Excel file). Although lake sites were sampled at multiple depths, only data collected from near-surface waters are summarized in this 
report. The USGS also collected mid-depth and near-bottom samples for nutrients, iron, and manganese at all lake sites. These data may be obtained from NWIS-Web or by request from the USGS North Carolina Water Science Center.

In-stream water-quality standards have been adopted by the North Carolina Division of Water Quality for 23 constituents monitored by the TAWSMP (table 2). All project sampling sites are in waters classified for water-supply use; therefore, applicable standards are the most stringent values established to protect freshwater aquatic life, water supply, or human health (North Carolina Department of Natural Resources, Division of Water Quality, 2007b). Concentration ranges that are shown in table 2 in bold font indicate that at least one sample for the constituent exceeded a North Carolina waterquality criterion at that location. Federal maximum contaminant levels (MCLs) and secondary drinking-water regulations (SDWRs) have been established by the U.S. Environmental Protection Agency for 20 of the monitored constituents (http://www.epa.gov/safewater/contaminants/index.html). These criteria are applicable only to treated potable water - not to raw water supplies; however, they are provided here for reference.

No exceedances of State water-quality criteria were observed for 13 of the 23 constituents for which standards exist, including hardness, chloride, fluoride, sulfate, nitrate, arsenic, cadmium, chromium, lead, molybdenum, nickel, selenium, and silver. Exceedances were observed for nine water-quality constituents, including dissolved oxygen, dissolved oxygen percent saturation, $\mathrm{pH}$, chlorophyll $a$, filterable and total recoverable mercury, copper, iron, manganese, and zinc (table 2). Knap of Reeds Creek (site 8) was the only site sampled during water year 2008 that had no exceedances of water-quality standards for the constituents that were measured.

\section{Dissolved Oxygen, pH, and Conductance}

Dissolved-oxygen concentrations less than 5 milligrams per liter $(\mathrm{mg} / \mathrm{L})$ were observed occasionally at seven lake and three stream sites in the study area (table 2; fig. 6A). Low concentrations were reflective of the prevailing drought and stagnant conditions in selected streams and lakes. At the other extreme, lake sites occasionally showed supersaturated dissolved-oxygen concentrations and elevated $\mathrm{pH}$ during periods of active algal photosynthesis. Dissolved-oxygen saturation values greater than 110 percent can be interpreted as exceeding the dissolved gases standard and were recorded at seven lake sites (table 2; fig. $6 B$ ) typically during summer months when the lakes were thermally stratified. One dissolved-oxygen saturation value greater than 110 percent also was measured at White Oak Creek at mouth near Green Level (site 28) on August 4, 2008, when the stream had no measurable flow and excessive algal growths were observed at the site. A single $\mathrm{pH}$ value that exceeded the North Carolina water-quality standard of 9 was observed at Jordan Lake at Bells Landing (site 30) on October 17, 2007.

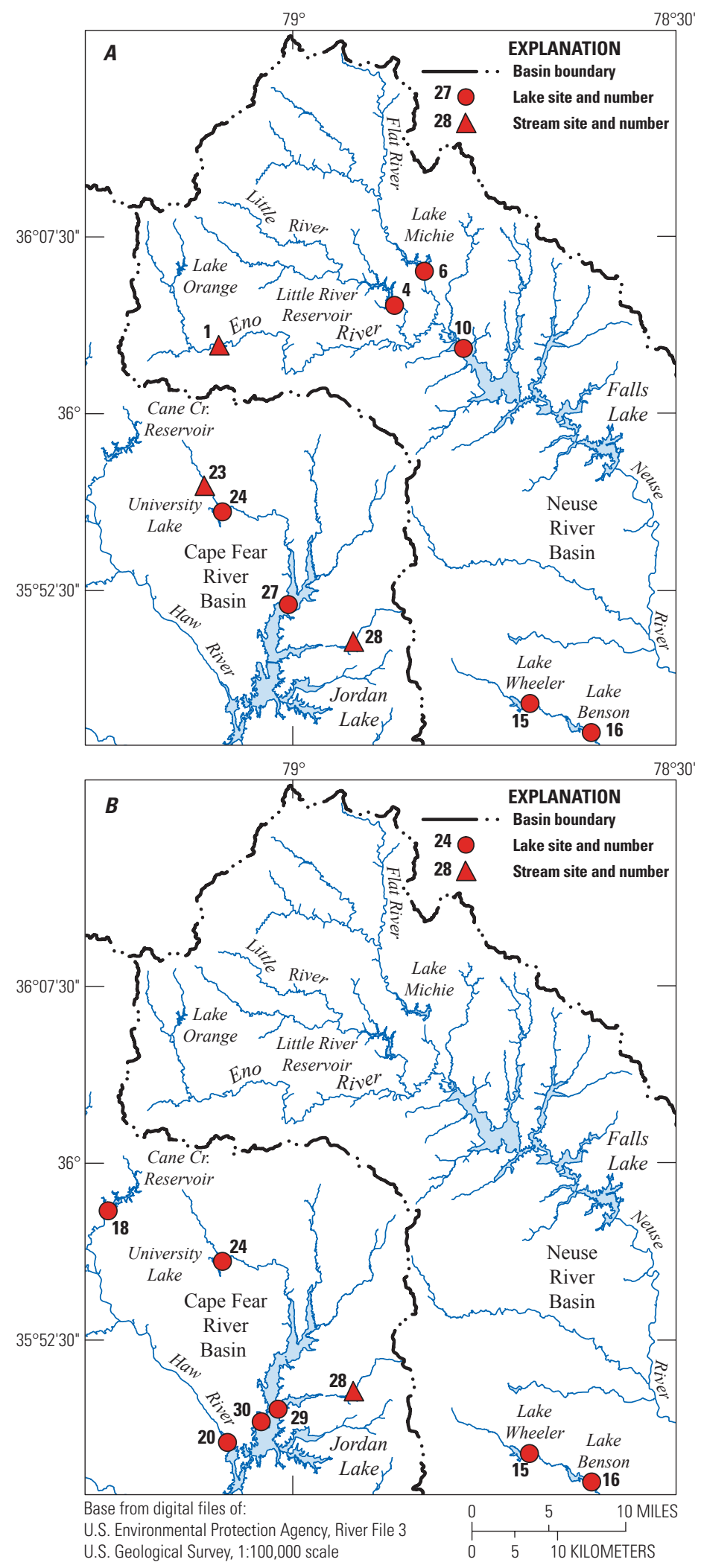

Figure 6. Sites in the Triangle area of North Carolina with one or more measurement of $(A)$ dissolved-oxygen concentration less than 5 milligrams per liter and $(B)$ dissolved-oxygen percent saturation value greater than 110 percent, 0 ctober 2007 through September 2008 (locations in fig. 1 and table 1). 
Although no standard has been adopted for specific conductance, interesting variations among sites have been shown for this constituent. The highest conductance values were recorded at Falls Lake at U.S. Interstate 85 (site 10) and Jordan Lake, Haw River arm (site 20). Lake Butner (site 7) had the lowest conductance values and greatest water transparency among the study lakes (table 2).

\section{Metals and Trace Elements}

Metals and trace element samples were collected twice per year at all stream and lake sites. In addition, iron and manganese were monitored at multiple depths during each lake-sampling event.

The State aquatic-life standard for total recoverable iron is $1,000 \mu \mathrm{g} / \mathrm{L}$; however, the NCDWQ is proposing to eliminate this standard in 2010 (http://h2o.enr.state.nc.us/csu/trirev_SW.html). Iron concentrations exceeded $1,000 \mu \mathrm{g} / \mathrm{L}$ at 10 streams and 1 lake site in the study area during water year 2008 (table 2; fig. 7A). Storm-related (runoff) stream samples consistently exceeded the standard. Iron concentrations in lake-surface samples were all less than $1,000 \mu \mathrm{g} / \mathrm{L}$, except for samples collected at Falls Lake at U.S. Interstate 85 (site 10; table 2), where four of the five samples had concentrations above the standard. Total recoverable manganese samples exceeded the $200 \mu \mathrm{g} / \mathrm{L}$ water-supply standard at nine lake sites and five streams sites during water year 2008 (table 2; fig. $7 B$ ). Iron and manganese tend to be substantially higher in lake-bottom waters than near-surface samples during summer stratification.

Mercury samples were collected at all sites during water year 2008 as part of a parallel investigation of mercury in the study area. Higher concentrations of mercury in water generally were observed in lakes compared to streams; however, some streams exceeded the $0.012-\mu \mathrm{g} / \mathrm{L}$ State standard during runoff events. Total recoverable mercury concentrations above the standard were measured at 17 stream and lake sites (table 2; fig. 7C); at 9 of those sites, filterable mercury also exceeded the standard at least once during water year 2008 (table 2). A maximum concentration of $0.235 \mu \mathrm{g} / \mathrm{L}$ total recoverable mercury was recorded at Falls Lake at NC Highway 50 (site 12) on October 3, 2007. All mercury concentrations were less than the Federal drinking-water MCL of $2 \mu \mathrm{g} / \mathrm{L}$.

Copper concentrations greater than the State water-quality standard of $7 \mu \mathrm{g} / \mathrm{L}$ were measured at four stream sites: Little River (site 3), Ellerbe Creek (site 9), New Hope Creek (site 21), and Northeast Creek (site 22). All samples with total recoverable copper concentrations greater than $7 \mu \mathrm{g} / \mathrm{L}$ were collected from streams in association with runoff events (table 2; fig. 7D). A maximum concentration of $17.4 \mu \mathrm{g} / \mathrm{L}$ was recorded at Little River on September 6, 2008. The only concentration of zinc that was greater than the State water-quality standard of $50 \mu \mathrm{g} / \mathrm{L}$ occurred at Ellerbe Creek on September 6, 2008 (52.8 $\mu \mathrm{g} / \mathrm{L})$. Overall, zinc concentrations were lower at lake sites than at stream sites (table 2).
With the exception of aluminum, iron, and manganese, all metal and trace element concentrations were less than Federal drinking-water MCLs or SDWRs (table 2) during water year 2008. As noted previously, MCLs and SDWRs are applicable to treated drinking water rather than untreated source water; however, they are included in this report for reference. Aluminum, iron, and manganese concentrations occasionally exceeded SDWRs (table 2); however, concentrations were similar to those observed in the study area during previous years (http://wdrwater.usgs.gov/).

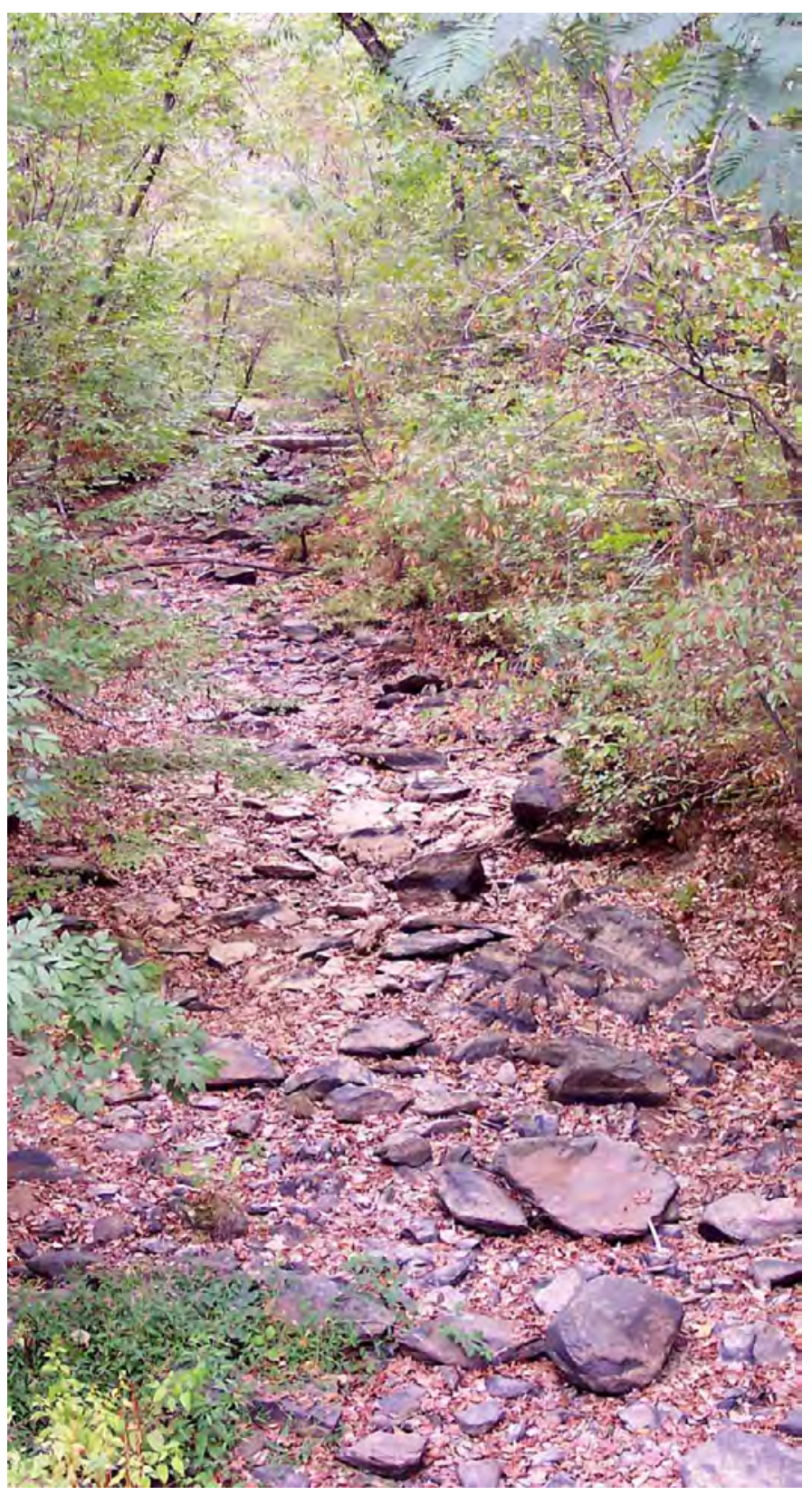

Dry streambed at site 17, Cane Creek near Orange Grove, North Carolina, October 2, 2007. (Photograph by R.B. Rasmussen, U.S. Geological Survey) 

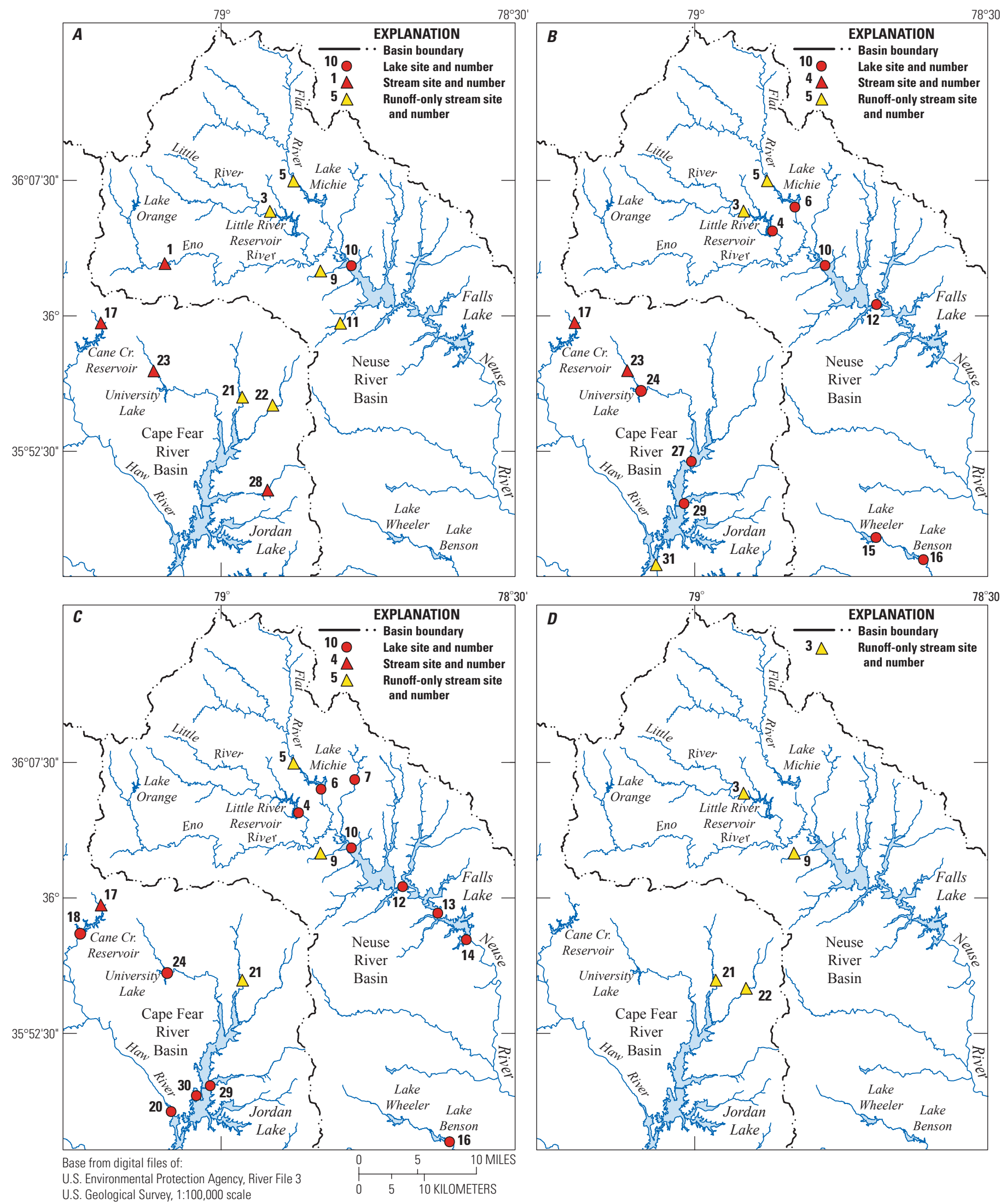

Figure 7. Sites in the Triangle area of North Carolina with one or more concentration of $(A)$ unfiltered iron greater than 1,000 micrograms per liter, $(B)$ unfiltered manganese greater than 200 micrograms per liter, $(C)$ unfiltered mercury greater than 0.012 microgram per liter, and $(D)$ unfiltered copper greater than 7 micrograms per liter, October 2007 through September 2008 (locations in fig. 1 and table 1). 


\section{Chlorophyll a}

Concentrations of chlorophyll $a$ were measured only at lake sites. During water year 2008, concentrations greater than the North Carolina water-quality standard of $40 \mu \mathrm{g} / \mathrm{L}$ were observed at least once at 10 of the 15 lake sites, including Little River Reservoir, 3 sites in Falls Lake, Lake Benson, University Lake, and the 4 Jordan Lake sites (table 2; fig. 8). Seasonal patterns differed among lakes. A maximum chlorophyll $a$ concentration of $96 \mu \mathrm{g} / \mathrm{L}$ was recorded at University Lake on October 5, 2007. Hot, dry weather during October 2007 also provided an opportunity for algae to thrive at the four Jordan Lake sites and the two upstream sites in Falls Lake. During April 2008, concentrations greater than $40 \mu \mathrm{g} / \mathrm{L}$ were observed in Little River Reservoir and the near-dam site in Falls Lake. A chlorophyll $a$ concentration of $69.4 \mu \mathrm{g} / \mathrm{L}$ was measured at Lake Benson during August 2008. Lake Butner consistently had the lowest levels of chlorophyll $a$, with concentrations ranging from 1.9 to $6.3 \mu \mathrm{g} / \mathrm{L}$.

\section{Nitrogen and Phosphorus}

The USGS collected nutrient samples six times per year at 4 routine stream sites, four to six times per year at 15 lake sites, and during every sampling of 8 runoff-only stream sites. Nutrient fractions that were analyzed included total ammonia plus organic nitrogen (also known as total kjeldahl nitrogen), ammonia, nitrite, nitrate plus nitrite, orthophosphorus, and total phosphorus. Nutrient concentrations were within ranges observed during previous years (http://wdr.water.usgs.gov/). A State water-quality standard exists only for nitrate $(10 \mathrm{mg} / \mathrm{L})$, and no samples exceeded that concentration.

Total ammonia plus organic nitrogen concentrations ranged from $0.26 \mathrm{mg} / \mathrm{L}$ at Morgan Creek near White Cross (site 23) to $1.7 \mathrm{mg} / \mathrm{L}$ at Little River near Orange Factory (site 3 ) and varied widely among sites and sampling dates (table 2; fig. 9A). Total phosphorus concentrations ranged from $0.01 \mathrm{mg} / \mathrm{L}$ at Lake Butner (site 7) to $0.62 \mathrm{mg} / \mathrm{L}$ at Falls Lake at U.S. Interstate 85 (site 10; table 2; fig. 9B). Except for the maximum concentration, all other samples had concentrations less than

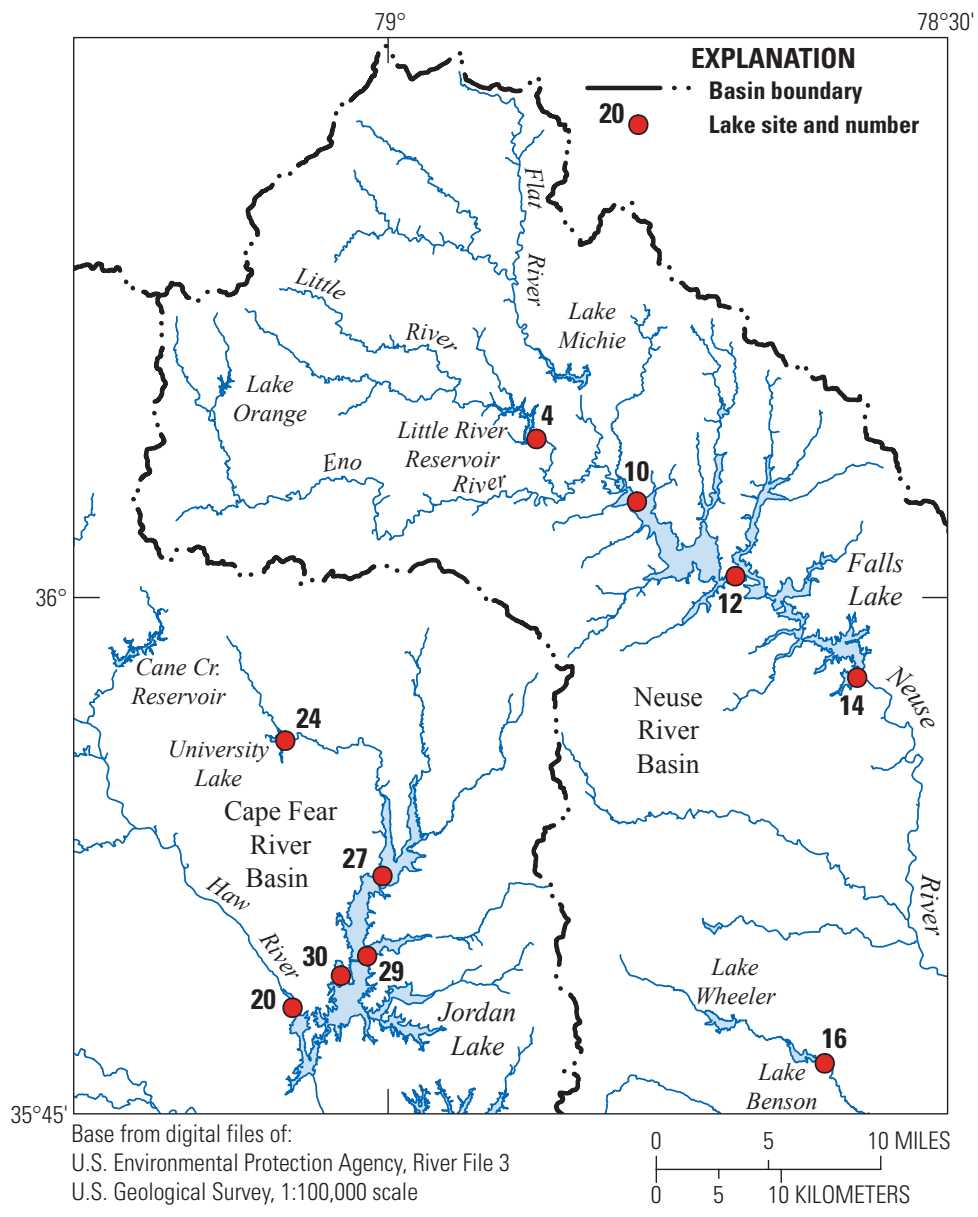

Figure 8. Sites in the Triangle area of North Carolina with one or more chlorophyll a concentration greater than 40 micrograms per liter, October 2007 through September 2008 (locations in fig. 1 and table 1). 
$0.4 \mathrm{mg} / \mathrm{L}$, and 80 percent of the samples had concentrations less than $0.1 \mathrm{mg} / \mathrm{L}$. Relatively higher concentrations (greater than $0.20 \mathrm{mg} / \mathrm{L}$ ) were recorded at the Falls Lake Interstate 85 site and in storm-event samples from Little River, Flat River, Ellerbe Creek, Little Lick Creek, and New Hope Creek (fig. 9B). Relatively lower concentrations (less than or equal to $0.05 \mathrm{mg} / \mathrm{L}$ ) were recorded at the Eno River at Hillsborough, several small lakes (Little River Reservoir, Lake Michie, Lake Butner, Lake Wheeler, and Cane Creek Reservoir), the two downstream sites in Falls Lake (site 13 and 14), Jordan Lake at Bells Landing (site 30), and White Oak Creek (fig. 9B).

Concentrations of ammonia, nitrite, nitrate plus nitrite, and orthophosphorus were less than laboratory reporting levels in $64,49,42$, and 71 percent of samples, respectively. Most reportable concentrations were noted in streams throughout the year and in lakes during fall through spring. As in previous years, lake sites generally had low concentrations of these dissolved, inorganic nutrient fractions near the water surface during summer months (June and August 2008) when nutrients tend to be taken up by phytoplankton. The somewhat riverine site 20, Jordan Lake Haw River arm, was an exception. Nitrate plus nitrite was above reporting levels during all six sampling events, ranging from 0.024 to $0.976 \mathrm{mg} / \mathrm{L}$ (table 2). Bottom-water concentrations of ammonia, orthophosphorus, and total phosphorus were higher than near-surface concentrations during the summer when lakes were thermally stratified, consistent with results from previous years (http://wdr.water.usgs.gov/). The highest concentrations reported in the study area for nitrate plus nitrite $(1.53 \mathrm{mg} / \mathrm{L})$, orthophosphorus $(0.417 \mathrm{mg} / \mathrm{L})$ and total phosphorus (0.62 mg/L) were observed on October 3, 2007 , at site 10, Falls Lake at U.S. Interstate 85 (table 2).
A. Total ammonia plus organic nitrogen (milligrams per liter as nitrogen)

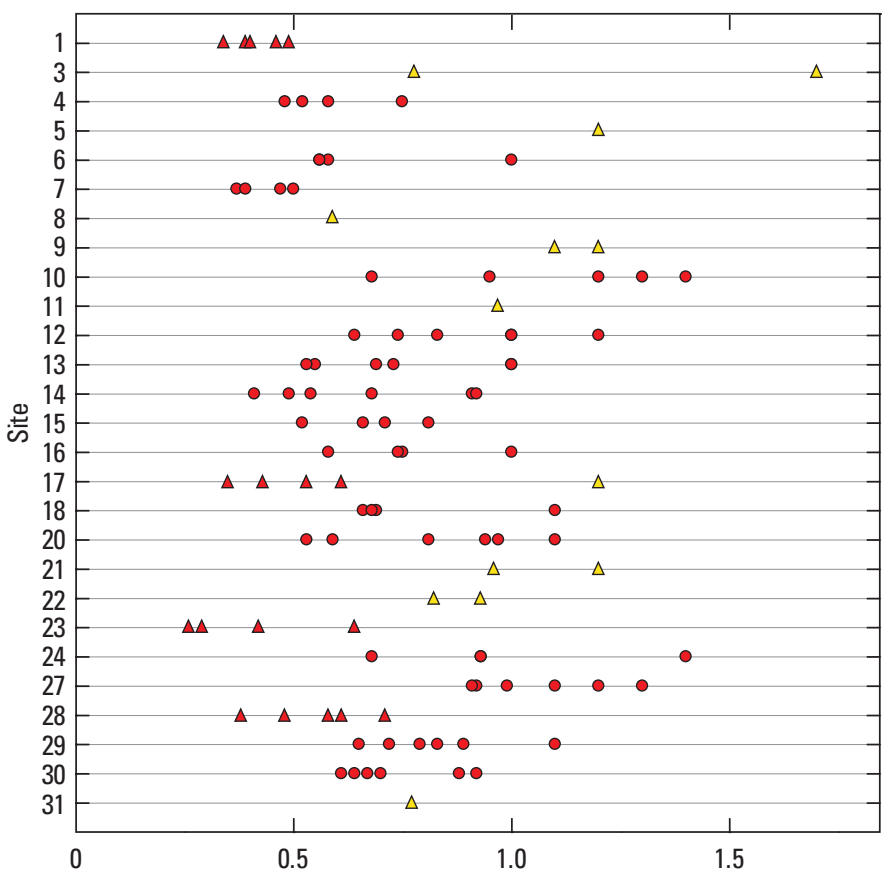

B. Total phosphorus (milligrams per liter as phosphorus)

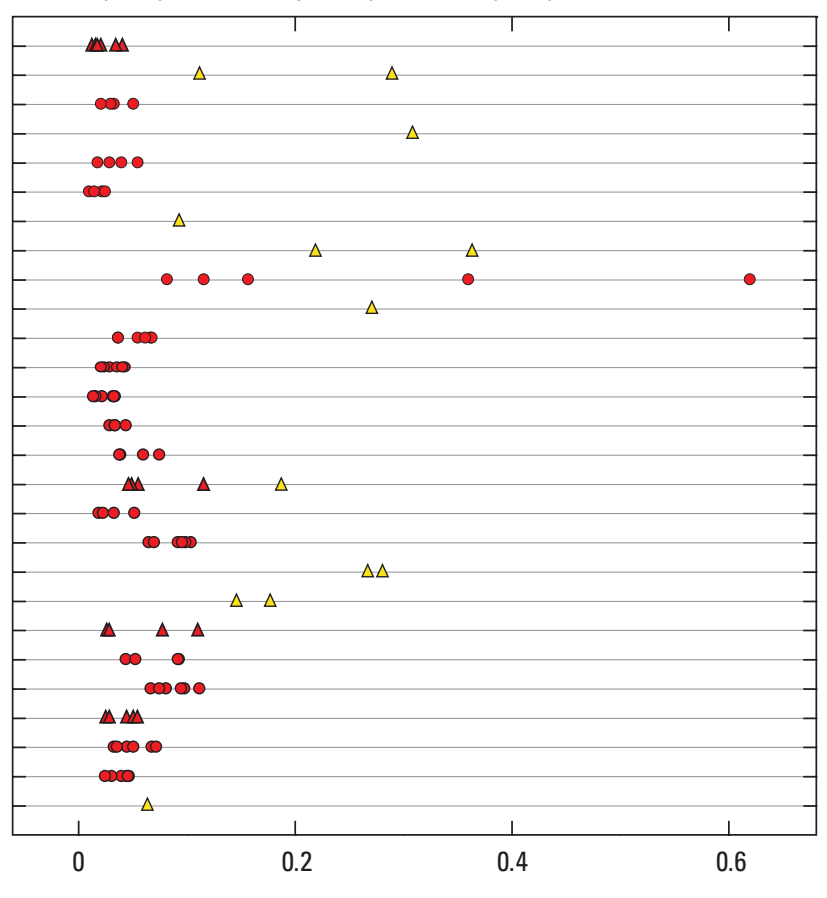

EXPLANATION

- Lake site routine sample

$\Delta$ Stream site routine sample

$\Delta$ Stream site runoff sample

Figure 9. Dot plots of concentrations of $(A)$ total ammonia plus organic nitrogen and $(B)$ total phosphorus at sites in the Triangle Area Water Supply Monitoring Project study area, October 2007 through September 2008 (locations in fig. 1 and table 1).

\section{What's Next?}

During 2009, the USGS plans to continue monitoring streamflow and water quality at the TAWSMP sites in the Upper Neuse and Cape Fear River Basins to include upgrading data transmitters at streamgages, which will allow hourly updates of critical water-level and streamflow data to the Web. The field data-collection phase of a special investigation of mercury in water and bed sediment is expected to be completed followed by data analysis and interpretation. Plans are to continue the analysis of long-term trends in selected water-quality constituents. 


\section{Quality of Surface-Water Supplies in the Triangle Area of North Carolina, Water Year 2008}

\section{References}

North Carolina Department of Environment and Natural Resources, Division of Water Quality, 2007a, North Carolina 2006 303(d) list, June 19, 2007: Raleigh, North Carolina Division of Water Quality, 125 p., accessed May 20, 2009, at: http://h2o.enr.state.nc.us/tmdl/documents/ 303d_Report.pdf.

North Carolina Department of Environment and Natural Resources, Division of Water Quality, 2007b, Surface waters and wetlands standards (May 1, 2007), NC Administrative Code 15A NCAC 2B: Raleigh, Environmental Management Commission, 134 p., accessed May 20, 2009, at: http://h2o.enr.state.nc.us/admin/rules/ codes_statutes.htm.

Oblinger, C.J., 2004, Triangle Area Supply Monitoring Project, October 1988 through September 2001, North Carolina-Description of the water-quality network, sampling and analysis methods, and quality-assurance practices: U.S. Geological Survey Open-File Report 2004-1278, $56 \mathrm{p}$.

State Climate Office of North Carolina, 2008a, Climate Division data, accessed July 21, 2009, at http://www.nc-climate.ncsu.edu/climate/climdiv.php.

State Climate Office of North Carolina, 2008b, NC CRONOS database, accessed November 21, 2008, at http://www.nc-climate.ncsu.edu/cronos. 


\section{Prepared by}

U.S. Geological Survey

Science Publishing Network

Raleigh Publishing Service Center

3916 Sunset Ridge Road

Raleigh, NC 27607

A PDF version of this publication is available online at http://pubs.usgs.gov/of/2012/1013/ 
